\title{
ANALISIS DAN PERACANGAN DATA ANGGOTA DPRD BERBASIS DATABASE PADA SEKETARIAT DPRD KABUPATEN BATU BARA
}

\author{
DATA ANALYSIS AND DESIGN OF DATA BASED ON THE DATABASE OF THE DPRD \\ MEMBERS OF THE REGENCY OF BATU BARA DPRD
}

Muhammad Khairil Mahbub Elby ${ }^{1}$, Andri Gunawan², Ikhwan Dhani Alfarhabi ${ }^{3}$
Program Studi Ilmu Komputer Fakultas Sains Dan Teknologi, Universitas Islam Negeri Sumatera Utara
E-mail: 1elbykhairil@gmail.com, ${ }^{2}$ andrigunawan1011@gmail.com,
${ }^{3}$ dhanialfikhwan@gmail.com

\begin{abstract}
Abstrak
Sekretariat DPRD memiliki permasalahan berkaitan dengan pengarsipan data diri Anggota DPRD Kabupaten Batu Bara yang terkadang susah diakses. Hal itu dikarenakan karena sekretariat DPRD Kabupaten Batu Bara masih mengarsipkan seluruh data anggota DPRD didalam penyimpanan komputer yang terkadang hilang atau bahkan rusak akibat virus, kerusakan perangkat dan sebagainya, selain itu data tidak bisa di akses dari tempat lain karena tertinggal di PC sekretariat DPRD. Tujuan dari penelitian ini adalah untuk menganalisa dan merancang prototype Sistem Informasi Data Diri Anggota DPRD Kabupaten Batu Bara berbasis Database, dengan metode arsitektur HMVC (Hierarchical Model View Control) pada MySQL PHPMyAdmin sebagai DBSM-nya yang diharapkan dapat membantu memudahkan pembuatan database yang kompetibel sesuai kebutuhan. Sehingga dapat meminimalisir hilang atau rusaknya data diri Anggota DPRD Kabupaten Batu Bara, selain itu juga bisa diakses dimanapun tanpa harus membuka arsip di PC Sekretariat DPRD.
\end{abstract}

Kata Kunci : Analisis, Perancangan, PHPMyAdmin, HMVC, Arsip DPRD.

\begin{abstract}
The DPRD Secretariat has a problem related to archiving the personal data of the Batu Bara DPRD Members, which is sometimes difficult to access. This is because the Batu Bara DPRD secretariat still archives all DPRD member data in computer storage which is sometimes lost or even damaged due to viruses, device damage and so on, besides that data cannot be accessed from other places because it is left on the DPRD secretariat PC. The purpose of this study was to analyze and design a prototype of the Database-based Personal Data Information System for Members of DPRD Batu Bara Regency, with the HMVC (Hierarchical Model View Control) architectural method on MYSQL PHPMyAdmin as the DBSM which is expected to help facilitate the creation of a database that is compatible as needed. . So that it can minimize the loss or damage of personal data for members of the Batu Bara Regency DPRD, besides that it can also be accessed anywhere without having to open the archive on the DPRD Secretariat PC.
\end{abstract}

Keywords: Analysis, Design, PHPMyAdmin, HMVC, DPRD Archives.

\section{PENDAHULUAN}


Era digitalisasi membuat manusia semakin ingin menciptakan kemudahan didalam hidup tidak terkecuali dalam hal penyimpanan data. Penyimpanan data yang aman dan tidak perlu memakan ruang penyimpanan (seperti hardisk dan sebagainya) merupakan pilihan yang banyak digunakan oleh pengguna untuk menyimpan data karena lebih hemat dan jarang terserang virus, selain itu penyimpanan berbasis cloud juga lebih mudah untuk diakses dimana pun oleh pengguna tanpa harus membawa perangkat yang menyimpan data seperti PC. Penggunaan penyimpanan berbasis cloud diyakini lebih efisien dimasa sekarang ini mengingat tuntutan teknologi yang semakin meningkat seiring dengan kebutuhan pengguna. Tidak terkecuali Instansi-Instansi besar seperti Sekretariat Dewan Perwakilan Rakyat Kabupaten Batu Bara yang memerlukan sebuah media pengarsipan data yang salah satunya data diri para Anggota Dewan Perwakilan Rakyat.

Fungsi file sangat penting dalam proses organisasi, baik itu organisasi pemerintah (publik) atau organisasi swasta (profit). Manfaat arsip bagi organisasi, antara lain informasi yang berguna untuk pengambilan keputusan, dapat juga digunakan sebagai bukti adanya permasalahan, dapat juga digunakan sebagai alat akuntabilitas manajemen, dan dapat digunakan sebagai alat untuk meningkatkan transparansi sebagai wujud dari birokrasi. Selain itu, jika arsip dikelola dengan tertib akan sangat bermanfaat bagi organisasi, tetapi sebaliknya jika arsip dikelola dengan tertib akan menimbulkan masalah bagi organisasi. Penumpukan file-file yang tidak berguna dan sistem file yang tidak tepat akan membuat ruangan terasa sempit dan tidak nyaman, sehingga berdampak negatif terhadap kinerja tanggung jawab, fungsi dan fungsi utama peralatan tersebut. Jika file sulit ditemukan, maka menjadi kendala dalam proses pengambilan keputusan dan mempersulit akuntabilitas.[1]

Untuk mendukung dan membantu kelancaran kegiatan yang dilakukan oleh Sekretariat DPRD Kabupaten Batu Bara diperlukan data dan informasi dari arsip dan pihak terkait. Penulis melakukan wawancara kepada Kepala Bagian Umum Ibu Faridah Aryani, SH selaku KASUBBAG T.U DAN KEPEGAWAIAN mengenai permasalahan yang berkaitan tentang arsip di lingkungan Sekretariat DPRD Kota Batu Bara. Berikut beberapa permasalahan yang di sebutkan Ibu Faridah Aryani, SH: 1).Menyimpan, merawat dan memelihara arsip masih menggunakan media penyimpanan komputer dan hardcopy, 2). Pengaksesan data Anggota DPRD membutuhkan waktu karena keterbatasan PC, 3). Sering kehilangan berkas data Anggota DPRD yang diakibatkan kerusakan pada media penyimpanan seperti PC, 4). Proses pengaksesan yang relatif susah apalagi ketika sedang berada diluar kantor Sekretariat.

\section{METODE PENELITIAN}

Penelitian ini dilakukan dengan menggunakan metode penelitian HMVC (Hierarchical Model View Controller). Metode pengumpulan data adalah dengan mengumpulkan data-data arsip anggota DPRD di Kabupaten Batu Barra. Data yang digunakan adalah data informasi yang diperoleh di Kantor Sekretariat Dewan (Sekwan). HMVC adalah model yang sangat berguna untuk memecahkan masalah pengembangan sistem sederhana. Arsitektur HMVC (Hierarchical Model View Controller) merupakan pengembangan dari arsitektur MVC (Model View Controller). HMVC adalah sekumpulan pola MVC yang disusun dalam satu aplikasi. [2]

Penelitian dilakukan di Kantor Sekretariat DPRD Kabupaten Batu Barra. Arsitektur HMVC terdiri dari beberapa rangkap tiga, yang masing-masing tidak tergantung satu sama lain. Setiap bagian dapat meminta akses kebagian lain melalui pengontrolnya. Ini memungkinkan aplikasi untuk didistribusikan ke beberapa lokasi jika diperlukan.

Berikut Struktur HMVC : 


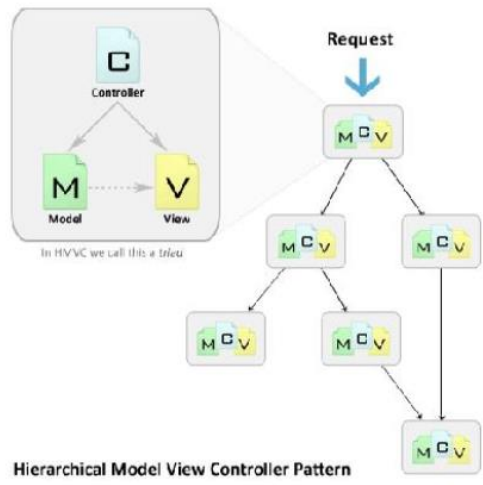

HMVC [3] (Cogan, 2010)

MySQL pertama kali dibuat oleh seorang programmer database bernama Michael Widenius. Server database MySQL adalah RDBMS (sistem manajemen database relasional) yang dapat menangani data dalam jumlah besar. Meski begitu, itu tidak membutuhkan banyak sumber daya. MySQL merupakan database yang paling populer diantara database lainnya. MySQL adalah perangkat lunak sistem manajemen database SQL atau DBMS. Database multi-threaded dan multi-user. [4]

PHP merupakan bahasa scripting yang berjalan pada sisi server (serverslide). Semua perintah tertulis akan dijalankan oleh server, dan hasil akhirnya dapat dilihat melalui browser. Saat ini, versi PHP 4 telah dirilis di pasaran, mewarisi kesuksesan versi sebelumnya, PHP 3. Selain digunakan di berbagai sistem operasi, koneksi database yang sangat sederhana membuat bahasa scripting ini sangat populer di Internet. programmer. Beberapa perintah PHP yang kita pelajari terbatas pada perintah yang menampilkan tag wml, mengakses database MySQL, dan mengirim email.[5]

XAMPP adalah software server Apache, database server di XAMPP sudah tersedia seperti pemrograman MySQL dan PHP. Kelebihan XAMPP adalah pengoperasiannya sangat sederhana, tidak memerlukan biaya apapun, dan mendukung instalasi di Windows dan Linux. Keuntungan lain yang Anda dapatkan adalah Anda hanya perlu menginstalnya satu kali, lalu sudah termasuk MySQL, Apache Web server, dukungan server database PHP (PHP 4 dan PHP 5), dan beberapa modul lainnya. Dari pengertian di atas dapat diketahui bahwa XAMPP merupakan software server apache yang memiliki banyak keunggulan seperti mudah digunakan, tidak dipungut biaya, dan mendukung instalasi Windows dan Linux. [6]

\section{HASIL DAN PEMBAHASAN}

Hasil dari analisis dan perancangan data Anggota DPRD Kabupaten Batu Bara berbasis database ini adalah terciptanya sebuah tabel database yang digunakan untuk menyimpan data seluruh Anggota DPRD Kabupaten Batu Bara, selain itu data yang disimpan juga ditampilkan dalam bentuk WEB guna memudahkan pengaksesan terhadap data tersebut. Hal ini diharapkan mampu menjadi pemecah permasalahan pengarsipan data Anggota DPRD Kabupaten Batu Bara yang masih menggunakan hardisc yang terkadang rusak atau hilang dan susah untuk di akses ketika berada diluar atau sedang tidak berada di kantor sekretariat.

Pembuatan tabel database menggunakan phpMyAdmin bertujuan untuk menampilkan data yang telah dibuat kedalam web browser menjadi kode HTML sehingga bisa dilihat dan 
diakses menggunakan web browser tanpa harus membuka file yang tersimpan didalam perangkat (PC) yang ada di sekretariat.

\section{Gambar 2.}

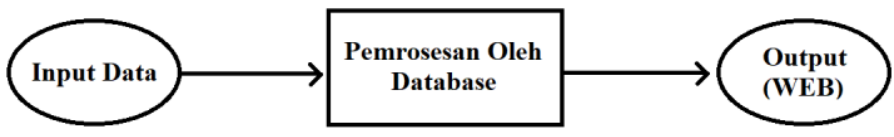

Rancangan

Database

Pada gambar diatas menjelaskan proses rancangan penginputan data yang akan dibuat untuk menyimpan data Anggota DPRD Kabupaten Batu Bara dengan tahapan pertama yaitu meng-input data yang ini dimasukkan, kemudian data akan diproses dan disimpan didalam database pypMyAdmin untuk selanjutnya ditampilkan dalam bentuk kode HTML ketampilan web browser.

Table 1. Rancangan Tabel Database Anggota DPRD

\begin{tabular}{|l|l|l|l|}
\hline Field Name & Data Type & Field Size & Keterangan \\
\hline No & Int & 10 & Nomor Urut \\
\hline Nama & Varchar & 250 & Nama \\
\hline Asal_Partai & Varchar & 250 & Asal Partai \\
\hline Jabatan & Varchar & 250 & Jabatan \\
\hline
\end{tabular}

Tabel diatas merupakan dari tabel database Anggota DPRD Kabupaten Batu Bara yang akan dibuat menggunakan database PHPMyAdmin, terlihat pada tabel tipe data dan ukuran dari setiap elemen yang akan dibuat didalam tabel database.

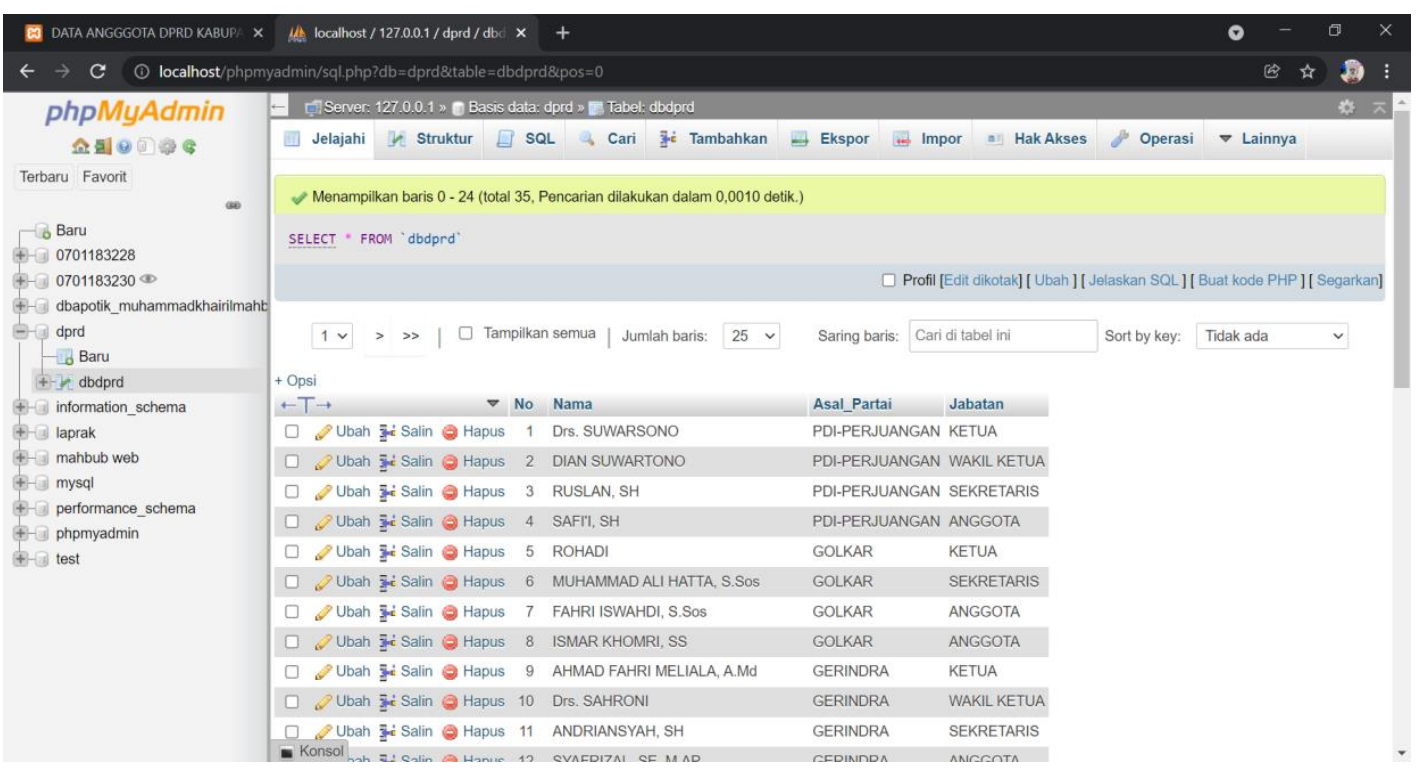

Gambar 3. Tabel Database DPRD Pada PHPMyAdmin 
Pada gambar diatas terlihat bahwa data Anggota DPRD Kabupaten Batu Bara sudah diinput dengan lengkap didalam tabel phpMyAdmin yang meliputi kolom untuk Nomor urut, Nama Anggota DPRD Kabupaten Batu Bara, Asal Partai, beserta jabatan dimasing-masing fraksi. Data-data yang terlihat diatas bisa diubah jika terdapat update yang terjadi dilapangan sehingga data tetap akurat dan terjaga.

Gambar 4. Tampilan Data Anggota DPRD Kab. Batu Bara Berbasis WEB

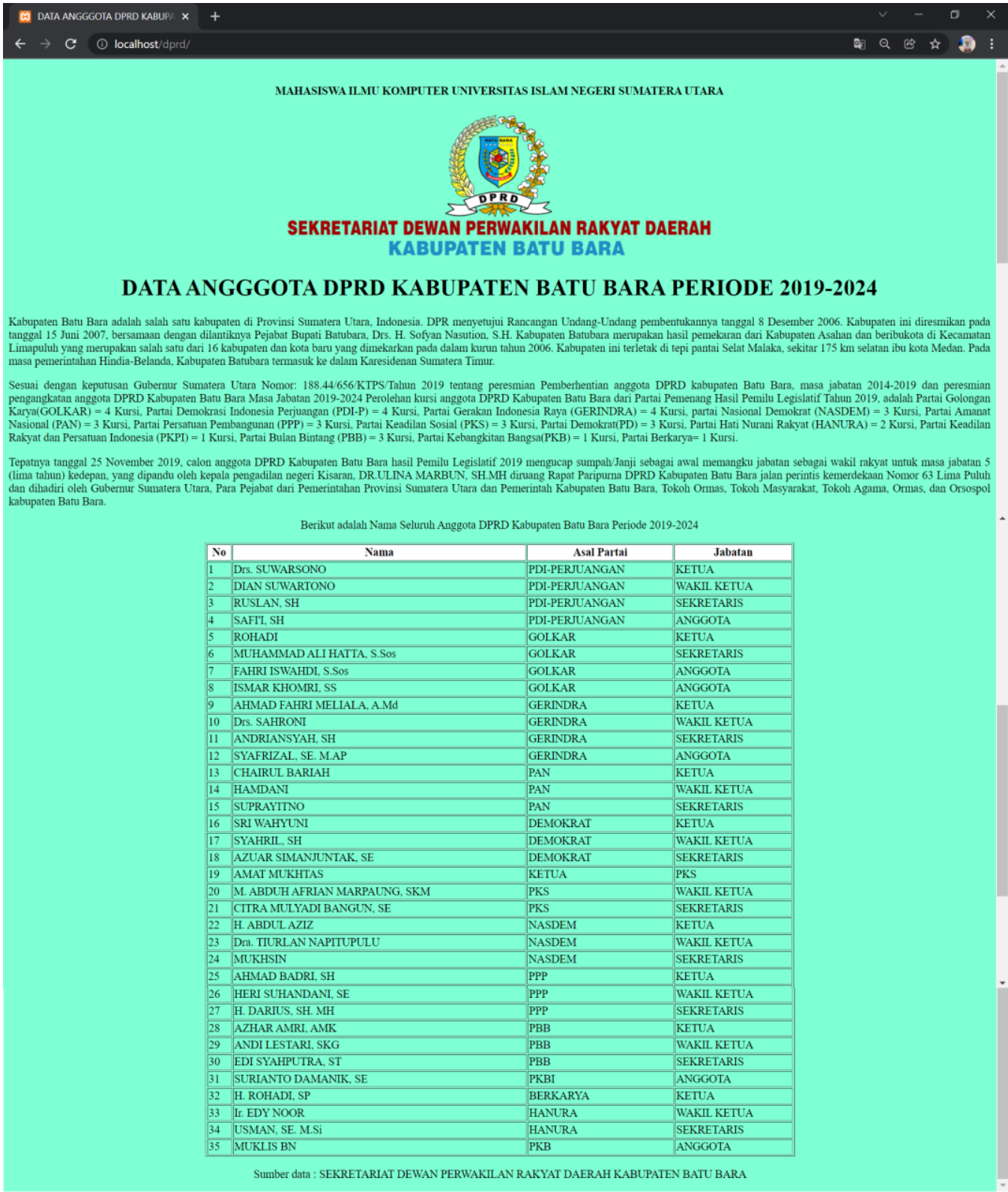

Gambar diatas memperlihatkan tampilan penuh dari data Anggota DPRD Kabupaten Batu Bara yang ditampilkan pada web browser yang bisa diakses oleh siapa pun dan dimana pun tanpa harus membuka data yang disimpan didalam arsip atau perangkat yang disimpan disekretariat DPRD Kabupaten Batu Bara. Seluruh data yang ditampilkan diatas bersumber dari kantor sekretariat Kabupaten Batu Bara, baik itu data Anggota DPRD Kabupaten Batu Bara periode 2019-2024, profil singkat Kabupaten, Dasar atau landasan hukum pengangkatan Anggota DPRD, serta Logo Sekretariat Kabupaten Batu Bara. 


\section{KESIMPULAN DAN SARAN}

Berdasarkan hasil dari Analisis Dan Perancangan Sistem Data Anggota DPRD Berbasis Database Pada Sekretariat DPRD Kabuaten Batu Bara dalam penelitian yang telah peneliti lakukan serta berdasarkan pembahasan yang telah di uraikan pada sebelumnya maka penulis dapat menarik kesimpulan dari permasalahan yang di hadapi Sekretariat DPRD Kabupaten Batu Bara sebagai berikut :

1. Pada penelitian ini menghasilkan rancangan Sistem Data Anggota DPRD Berbasis Database Pada Sekretariat DPRD Kabupaten Batu Bara yang dapat diterapkan sesuai dengan kebutuhan dalam pengolahan arsip agar dapat memudahkan pengelolaan data kearsipannya terutama dalam data Anggota DPRD.

2. Penelitian ini menggunakan metode pemodelan analisis sistem berbasis objek yaitu HMVC (Hierarchy Model View Controller).

3. Dengan adanya rancangan arsip data Anggota DPRD ini diharapkan dapat memudahkan pengguna atau petugas dalam melakukan pengolaan dan penjagaan arsip data Anggota DPRD pada Sekretariat Dewan Perwakilan Rakyat Daerah Kabupaten Batu Bara sebagai solusu untuk pemecahan permasalahan yang ada.

Berdasarkan penelitian yang ada, saran yang dapat diberikan sebagai berikut:

1. Rancangan Sistem Database ini perlu dikembangkan lebih lanjut, sehingga benar-benar bisa digunakan secara online dan dapat diterapkan pada Sekretariat DPRD Kabupaten Batu Bara untuk memudahkan dan membantu dalam proses pengarsipan data Anggota DPRD supaya tidak hilang atau susah diakses.

2. Dalam pengembangan Sistem Database ini belum memperhatian masalah keamanan data (security), maka dari itu peneliti mengharapkan penelitian lebih lanjut dapat melengkapi sistem keamanan datanya.

3. Dalam perancangan Sistem Database ini hanya menyediakan fasilitas terkait dengan data Anggota DPRD Kabupaten Batu Bara, maka untuk penelitian selanjutnya diharapkan dapat dilengkapi dengan pengelolaan data yang lain yang ada pada Sekretariat DPRD Kabupaten Batu Bara.

\section{DAFTAR PUSTAKA}

[1] Asnawi, Melan Angriani. 2009. Kontribusi Arsip Untuk Organisasi Publik. http://repository.ung.ac.id/get/simlit res/1/60/Kontribusi-Arsip-Untuk-OrganisasiPublik.pdf. Diakses pada tanggal 25 Oktober 2021

[2] Tanjung, Maulana Iqbal. 2011. Analisis dan Perancangan Sistem Infromasi Berbasis Website Menggunakan Arsitektur MVC dengan Framework Codeigniter. Yogyakarta : STMIK AMIKOM.

[3] Cogan, Barry. 2010. HMVC: An Introduction and Application. https://code.tutplus.com/tutorials/hmvc-an-introduction-andanpplication-net-11850.

Diakses pada tanggal 25 Oktober 2021

[4] Wahana. 2010. Panduan Belajar MySQL Database Server. Jakarta Selatan: MediaKita.

[5] Sanjaya, Ridwan dan Josua Tarigan. (2009). Creative Digital Marketing. Jakarta: PT Elex Media Komputindo. 
[6] Iqbal, M. (2019). 5 Jam Belajar PHP MySQL dengan Dreamweaver CS3. Yogyakarta: Deepublish Publisher. 